\title{
Rhythm and Vocabulary of Greek Hexameter: From Formula to Topolexis
}

\author{
Juan Sebastián Páramo Rueda \\ Universidad Nacional de Colombia \\ sebastianparamo@gmail.com \\ (D) 0000-0002-9994-6837
}

\author{
Anastasia Belousova \\ Universidad Nacional de Colombia / \\ Moscow State University, Russia \\ metroyritmo@gmail.com \\ (1) 0000-0002-0771-4271
}

\author{
Paula Ruiz Charris \\ Universidad Nacional de Colombia \\ kromyon@gmail.com \\ (1) 0000-0002-1792-6286
}

\begin{abstract}
The article discusses the results of our application of a computer program created for the automatic analysis of lexical distribution based on rhythmic position in Greek hexameter.

For this purpose, we introduce the concept of the topolexis (in Greek $\tau 0 \pi 0 \lambda \varepsilon \dot{\xi}$ เ५:

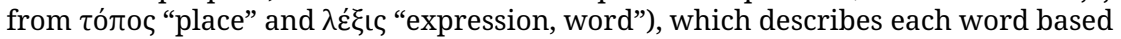
on its position in the given line and is expressed as the word in combination with

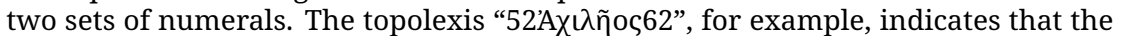

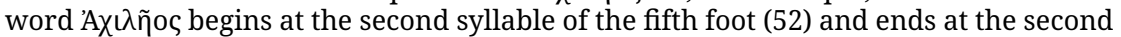
syllable of the sixth foot (62).

We investigate the behavior of topolexes in a corpus that includes Homer's The Iliad and The Odyssey and Apollonius Rhodius' The Argonautica. We find that the distribution of topolexes of different frequencies varies among these texts. While The Argonautica contains a greater number of unique topolexes, higher-frequency topolexes are more common in Homer's poems. The "formulaicity ratio", which we define as the ratio of distinct topolexes in a text to its overall topolexis count, is higher for Homer. In addition, we obtain and analyze data about Hesiod's The Theogony. Although The Theogony is only 1,023 lines long, it exhibits the same tendencies as Homeric hexameter. We are, thus, able to clearly and accurately compare the behavior of topolexes in epic hexameter in the formulaic style and in its literary imitation by Apollonius.

Lastly, we run a test to compare the performances of the topolexes and the most frequent words (MFW) as stylometric indicators for determining text authorship. We find that while topolexes enable us to correctly cluster fragments by their author, they do not outperform the MFW in this respect.
\end{abstract}




\section{Introduction}

The present study is devoted to the relationship between rhythm and vocabulary in verse, or more specifically, the organization of linguistic material within the poetic line. ${ }^{1}$ Our methodology is inspired by two research streams, of which one stems from work on verse syntax, which has been advancing in Russian verse studies since the 1920s, while the other is based on the oral-formulaic theory that originated with Milman Parry and Albert Lord's work on Homeric and other epic traditions.

The first of these two inspirations refers particularly to Osip Brik's work. In his pioneering study, "Ritm i sintaksis" (Rhythm and Syntax) (1927/2012), Brik pointed out that poetic speech reflects a dynamic interaction of rhythm, syntax, and semantics. He saw the most conspicuous display of this interaction in what he termed "rhythmic-syntactic clichés (formulae)": "A poetic cliché is precisely the result of a complete fusion of the rhythmic, syntactic, and semantic aspects of the poetic word [whereby] conventional word combinations are formed in [terms of] which the poet himself thinks" (Brik 2012, p. 520). Brik's ideas have been fruitfully developed by Russian verse scholars over the last century. Mikhail Gasparov's contribution is especially significant in this respect: drawing on Brik's and Boris Yarkho's ideas, Gasparov succeeded in creating a linguistically substantiated method, which he used to analyze a wealth of material. ${ }^{2}$ In particular, he claimed that "(a) a rhythmic cliché is a fixed sequence of rhythmic words (which in verse studies is referred to as word boundary line variation [словораздельная вариация] [...]; (b) a syntactic cliché is a recurring sequence of the same phrase/sentence constituents [...]; (c) a rhythmic-syntactic cliché is a combination of both [(a) and (b)] [...]; (d) a rhythmic-syntactic formula is a rhythmic-syntactic cliché involving the exact recurrence of one or more words" (Gasparov 1986, p. 189).

Gasparov's associates and followers have enhanced his methods and applied them to different poetic material in recent decades. In this way, they have also developed his theories about the relationship between rhythm and syntax (Akimova 2017a; Belousova et al. 2019; Kruglova et al. 2019; Tarlinskaja 2015; Tverianovich 2019).

The second methodological tradition that we draw on arose from the study of what are known as Homeric formulae. Parry and Lord set out to demonstrate that The Iliad and The Odyssey were, in fact, instances of oral poetry and that these formulae played a special role in the two texts. In this context, Parry defined a formula as "une expression qui est régulièrement employée, dans les mêmes conditions métriques, pour exprimer une certaine idée essentielle"3 (Parry 1928, p. 16; Lord 1960; Parry 1971). ${ }^{4}$ Curiously, Parry, like Brik, linked vocabulary, rhythm, and semantics together. In the years since, classical philologists and specialists in other types of epic have made copious and often extremely

1 The authors wish to thank the editors and anonymous reviewers of this volume for their insightful comments and suggestions.

2 Concerning Brik, Yarkho, Gasparov, and the history of the study of verse syntax, see Akimova 2012, 2015, 2017b, including an extensive bibliography; see also Tver' yanovich 2008, pp. 110-114.

3 "an expression regularly used under the same metrical conditions to express an essential idea".

4 For a discussion of and amendments to this definition and related amendments, see Nagy 1990. 
productive efforts to apply the oral-formulaic theory to texts from various poetic traditions (see Foley 1985).

Predictably the advent of computer tools has also prompted an everincreasing number of statistical analyses of the formulaic style. In the second edition of his influential book on The Iliad, Martin Mueller, thus, added an entire chapter called "Homeric Repetitions" (2009, pp. 135-172) which used statistics to describe the workings of recurring elements in the Homeric epic. More recently, Sklaviadis et al. (2019) have completed a similar study that uses $n$-gram analysis and independently confirms Mueller's findings. This work also examines recurrences in relation to their linear location by identifying the positions within hexameter verse where $n$-grams recur most often (2019, p. 243 Fig. 4).

The current study continues this search for applications of computer-aided analysis of the formulaic style. While the new methodology that we propose does not directly evolve from any of the approaches described above, it is our hope that it will produce more in-depth analysis and more accurate descriptions of recurring lexical-rhythmic elements in Greek hexameter and verse in general.

\section{Method}

We developed a Python program called Hexametron that automatically scans Greek hexameter. This program is also able to process lines that present challenges because, for example, they contain the false diphthongs $\varepsilon \omega$ and $\varepsilon \alpha$, omit a consonant whose presence in a word must be assumed (e.g. $\check{\varepsilon} \delta \mathrm{F} \varepsilon$ เ $\sigma \varepsilon$ instead of ع $\delta \varepsilon(\sigma \varepsilon)$, or include a caesura in the third foot that must be assumed to produce

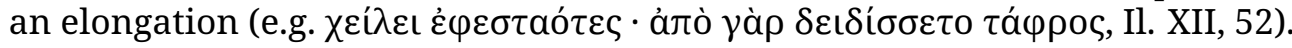
Of the 15,682 total lines in The Iliad, Hexametron correctly scanned 15,328, that is, $97.7 \%$.

Using Hexametron's output, we developed a second program that associates each word with its position within the hexameter. We named this association

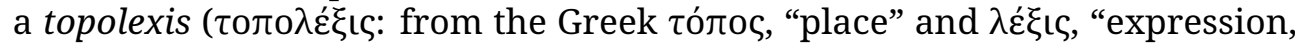

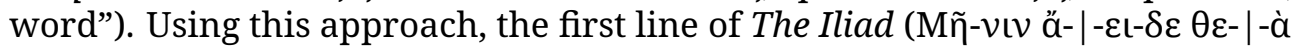

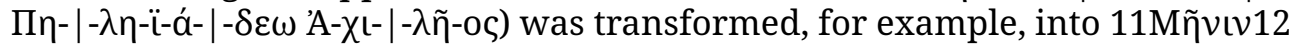

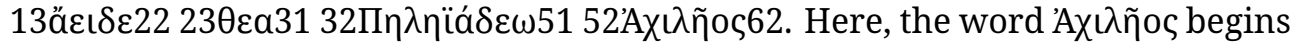
at the second syllable of the fifth foot (52) and ends at the second syllable of the sixth foot (62) while the word $\theta \varepsilon a$ begins at the third syllable of the second foot (23) and ends at the first syllable of the third foot (31). As can be seen, in these double-digit numbers that precede or follow the word, the first digit refers to the foot where the word begins or ends and the second to the syllable in that foot.

To explore the behavior of topolexes, we ran a series of tests on a textual corpus consisting of portions of The Iliad (the first 5,837 lines) and The Odyssey (the first 5,837 lines) and the entire text of Apollonius Rhodius' The Argonautica (5,837 lines). The size of the text sample was, of course, determined by the length of the shortest text (Argonautica). For each text, we established all of 


\begin{tabular}{|c|c|c|c|c|c|}
\hline \multicolumn{2}{|c|}{ The Iliad, 1-5837 } & \multicolumn{2}{|c|}{ The Odyssey, 1-5837 } & \multicolumn{2}{|c|}{ The Argonautica } \\
\hline Topolexis & Rec. & Topolexis & Rec. & Topolexis & Rec. \\
\hline $12 \delta^{\prime} 12$ & 356 & $12 \delta^{\prime} 12$ & 349 & $21 \delta^{\prime} 21$ & 221 \\
\hline $21 \delta^{\prime} 21$ & 247 & 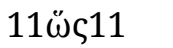 & 239 & $12 \delta^{\prime} 12$ & 184 \\
\hline 33каí33 & 203 & $21 \delta^{\prime} 21$ & 229 & $32 \tau \varepsilon 32$ & 167 \\
\hline 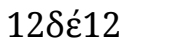 & 199 & 33каí33 & 215 & 11кaí11 & 142 \\
\hline 32каí32 & 193 & 11кaí11 & 184 & 33каí33 & 136 \\
\hline 42каí42 & 169 & $22 \delta^{\prime} 22$ & 183 & $22 \delta^{\prime} 22$ & 125 \\
\hline $22 \delta^{\prime} 22$ & 165 & $11 \alpha^{\prime} \lambda \lambda{ }^{\prime} 11$ & 178 & $32 \delta \varepsilon ́ 32$ & 121 \\
\hline 11кaí11 & 160 & 32каí32 & 177 & $52 \delta \varepsilon ́ 52$ & 121 \\
\hline $11 \alpha \dot{\alpha} \lambda \lambda^{\prime} 11$ & 158 & 42каı́42 & 162 & 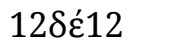 & 113 \\
\hline 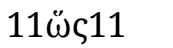 & 150 & $32 \tau \varepsilon 32$ & 145 & 22кaí22 & 112 \\
\hline
\end{tabular}

Table 1: The most common topolexes and their recurrence

the topolexes that it contained as well as the number of times that each one appeared.

\section{Findings and Data Analysis}

Table 1 presents the 10 most common topolexes along with the number of times they occur in each text. As the table makes clear, each topolexis contains a coordinating conjunction that occurs in various positions in the hexameter (the

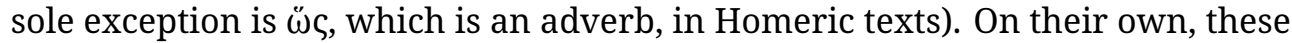
data shed some light on the functioning of hexametric lines and their syntactic tendencies. ${ }^{5}$

We were, however, primarily interested in the recurrence of content words and their distribution. For this reason, we excluded all function words from our lists by applying a stop-word list (this included conjunctions, articles, demonstrative adverbs, and pronouns). Having, thus, filtered our data, we obtained the results given in Table 2 (for the full data, see footnote 5 ).

Figure 1 is a line-plot which represents the 20 most common topolexes. These are sorted in descending order by frequency ( $x$-axis) and number of recurrences ( $y$-axis) and plotted on a logarithmic scale. As can be seen, The Argonautica differs strikingly from Homer's works: there are fewer recurrences of the most common topolexes in the former than in the latter.

Table 3 shows the number of topolexes that occur between 1 and 20 times in each sample (for the full data, see footnote 5). Here the first row gives the number of unique topolexes in each text while subsequent entries list the number of topolexes that recur, for example, 3, 10, 15, and 17 times. We can see that in The Iliad, for example, there are 14 topolexes that recur 16 times while there are 12 such topolexes in The Odyssey and 3 in The Argonautica.

5 The full data are available in CSV format at https://cutt.ly/ohzJfjY. 


\begin{tabular}{|c|c|c|c|c|c|}
\hline \multicolumn{2}{|c|}{ The Iliad, 1-5837 } & \multicolumn{2}{|c|}{ The Odyssey, 1-5837 } & \multicolumn{2}{|c|}{ The Argonautica } \\
\hline Topolexis & Rec. & Topolexis & Rec. & Topolexis & Rec. \\
\hline 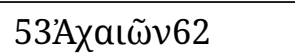 & 104 & 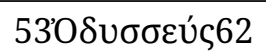 & 72 & 42à̀ óৎ43 & 30 \\
\hline 53Ахаเоí62 & 62 & 53Аดท́ขท 62 & 60 & 51Aińtao62 & 27 \\
\hline 52А $\gamma \alpha \mu \varepsilon ́ \mu \nu \omega \nu 62$ & 61 & $61 \theta v \mu \tilde{\omega} 62$ & 44 & 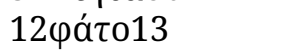 & 25 \\
\hline 53АХаıоós62 & 46 & 61عĩvai62 & 40 & $13 \ddot{\varepsilon} \varphi \eta 21$ & 24 \\
\hline 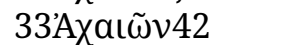 & 44 & $12 \varepsilon ̋ \varphi \alpha \tau^{\prime} 13$ & 38 & $11 v \tilde{n} a 12$ & 23 \\
\hline $32 \pi \rho о \sigma \varepsilon ́ \varphi \eta 41$ & 44 & $53 \theta a \lambda a ́ \sigma \sigma \eta \varsigma 62$ & 36 & 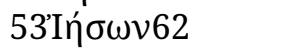 & 23 \\
\hline $53 \mu a ́ x \varepsilon \sigma \theta a ı 62$ & 39 & $32 \pi \rho о \sigma \varepsilon ́ \varphi \eta 41$ & 34 & 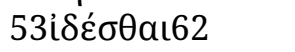 & 22 \\
\hline 53Аดท่́vฤ62 & 39 & 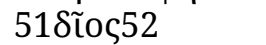 & 33 & 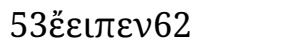 & 22 \\
\hline 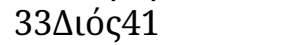 & 35 & 330عoí41 & 33 & 33வ เóৎ41 & 20 \\
\hline 61їлточқ62 & 35 & 330عá41 & 32 & $52 \pi \rho о \sigma \varepsilon ́ \varepsilon เ \pi \varepsilon \nu 62$ & 20 \\
\hline
\end{tabular}

Table 2: The most common topolexes and their recurrence (content words only)

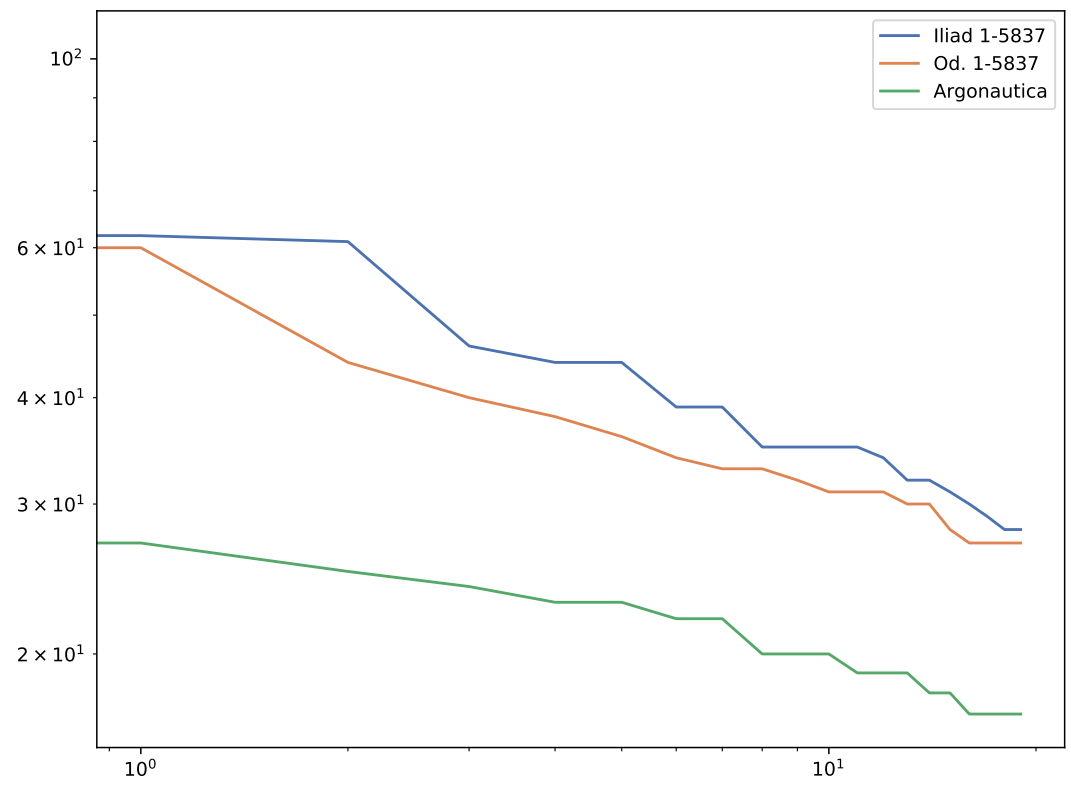

Figure 1: The 20 most common topolexes (content words only) and their recurrence plotted on a logarithmic scale

The number of unique topolexes in The Argonautica also turns out to be $20 \%$ higher than the figure for The Iliad and 26\% higher than the result for The Odyssey. Notably, the results for topolexes that recur 2 to 10 times are somewhat similar across all three texts. However a trend emerges when we consider topolexes that recur more than 10 times: there are fewer of these higher-frequency topolexes in The Argonautica than in the two Homeric texts. Figure 2 plots the data in Table 3 on a logarithmic scale. We can see a clear differ- 


\begin{tabular}{lccc}
\hline Frequency & The Iliad, 1-5837 & The Odyssey, 1-5837 & The Argonautica \\
\hline 1 & 9599 & 9120 & 11517 \\
2 & 2004 & 2018 & 1968 \\
3 & 750 & 790 & 708 \\
4 & 361 & 374 & 296 \\
5 & 212 & 221 & 164 \\
6 & 132 & 146 & 120 \\
7 & 82 & 86 & 75 \\
8 & 61 & 55 & 54 \\
9 & 39 & 47 & 35 \\
10 & 31 & 23 & 21 \\
11 & 29 & 22 & 15 \\
12 & 26 & 18 & 6 \\
13 & 14 & 23 & 6 \\
14 & 9 & 17 & 6 \\
15 & 12 & 7 & 10 \\
16 & 14 & 12 & 3 \\
17 & 7 & 8 & 4 \\
18 & 5 & 10 & 2 \\
19 & 5 & 6 & 3 \\
20 & 4 & 6 & 3 \\
\hline
\end{tabular}

Table 3: Total number of topolexes of each frequency (content words, from 1 to 20)

ence between The Iliad and The Odyssey on the one hand and The Argonautica on the other: high-frequency topolexes occur at a higher rate in the Homeric works.

Based on the same dataset, if we increase our range to the 50 most common topolexes and normalize the values, we obtain the results in Figure 3 (violin plot). This graph is probably most representative. It clearly shows that the distribution of topolexes of various frequencies is nearly identical in the two Homeric poems and very different in Apollonius' text. In addition, we see a thickening of The Argonautica graph that reflects its greater number of unique topolexes compared to the Homeric samples. In contrast, the thickening in the top part of the graphs for The Iliad and The Odyssey corresponds to their higher count of high-frequency topolexes.

Finally, we wished to investigate the correlation between the total number of topolexes and the number of recurring topolexes in our texts. To do this, we used the following formula:

$$
F R=\frac{\text { total number of topolexes }}{\text { number of distinct topolexes }}
$$




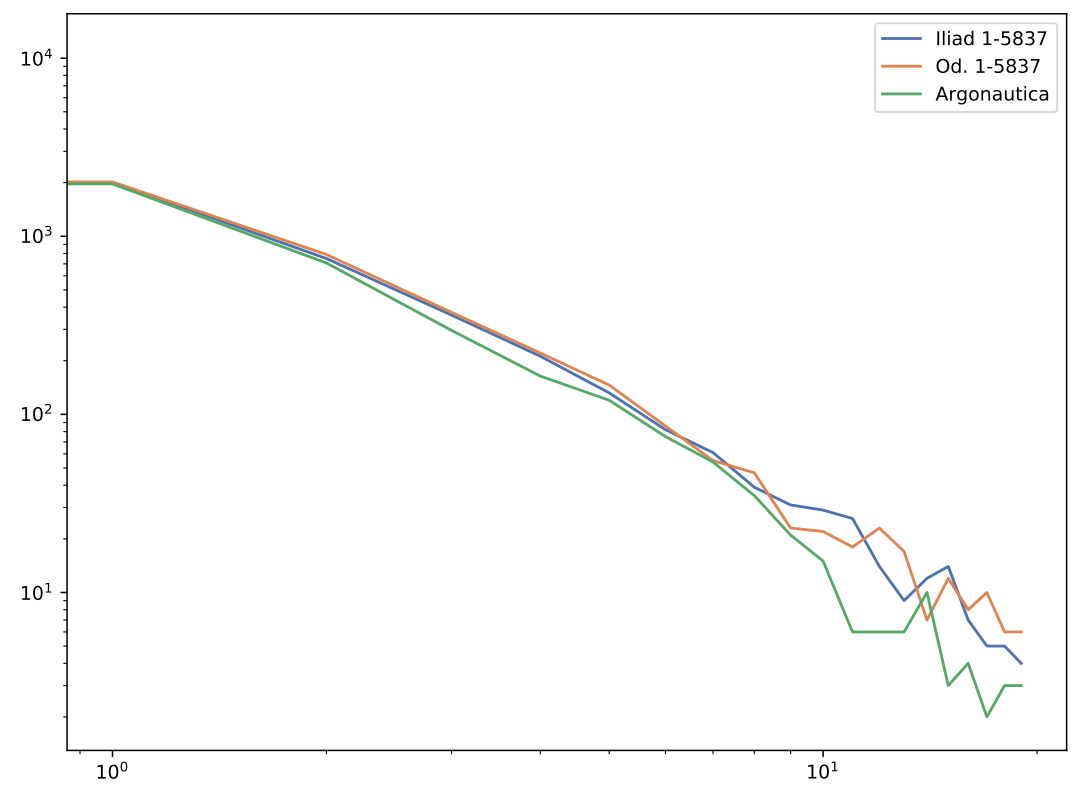

Figure 2: Total number of topolexes of each frequency (content words, from 1 to 20) plotted on a logarithmic scale

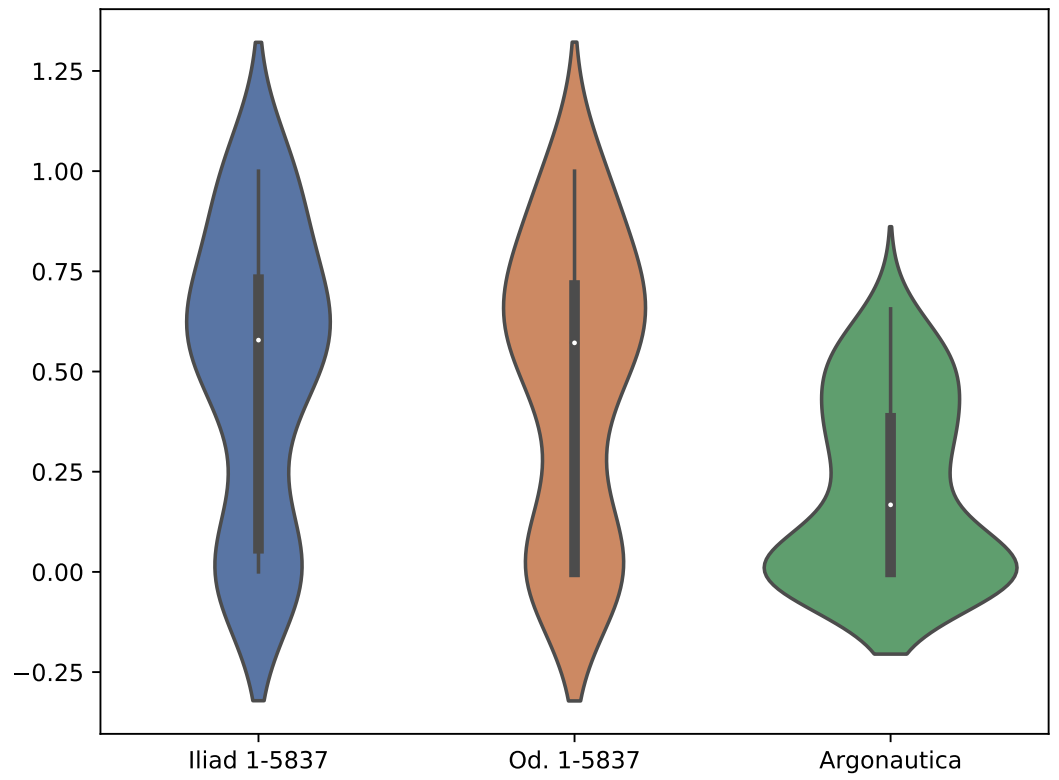

Figure 3: Total number of topolexes of each frequency (content words, from 1 to 50); normalized data 


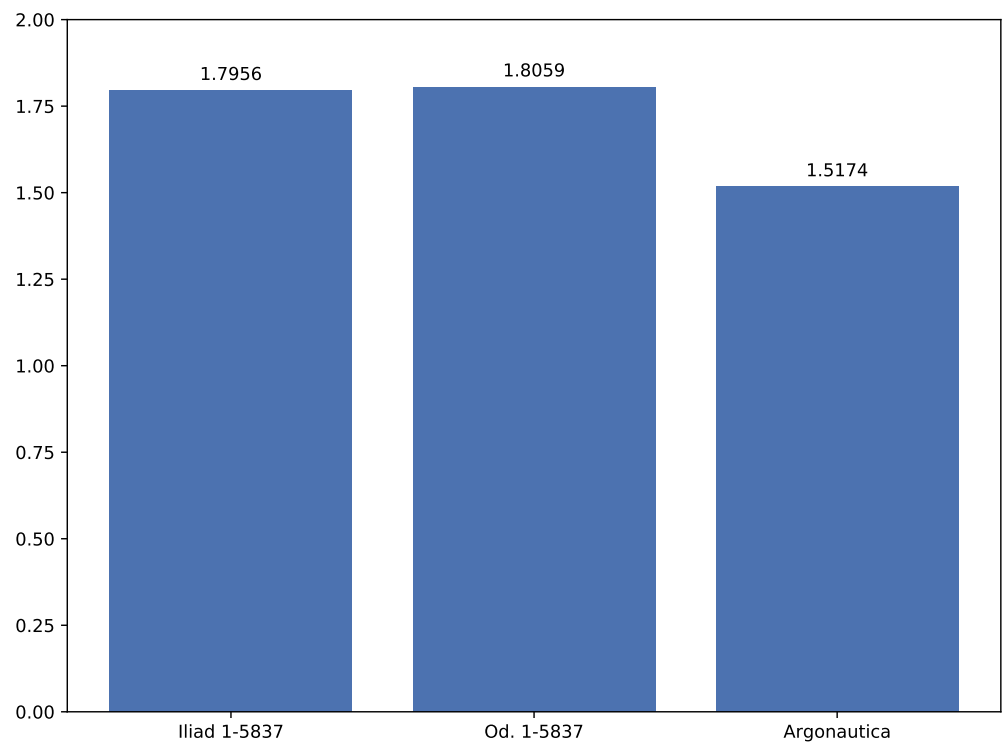

Figure 4: Formulaicity ratios

We called the resulting number the "formulaicity ratio". ${ }^{6}$ Figure 4 shows our results for the three samples (The Iliad: 1.80; The Odyssey: 1.81; The Argonautica: 1.52).

The formulaicity ratio was, thus, higher for The Iliad and The Odyssey than it was for The Argonautica. This suggests that the Homeric texts contained a lower number of unique topolexes, that is, they showed greater "formulaicity".

\section{Analysis of an Additional Corpus Including Hesiod's Hexa- meter}

We wished to apply the analysis above to a corpus that included an additional sample of Ancient Greek hexameter: Hesiod's The Theogony. There are only 1,023 lines in this text so its inclusion in the main corpus would have excessively reduced the size of the other sample texts. After selecting fragments of the same size from The Iliad, The Odyssey, and The Argonautica, we therefore compiled a new corpus. The line plot in Figure 5 depicts the 20 most common topolexes in each text, as sorted in descending order by frequency ( $x$-axis) and number of recurrences ( $y$-axis) and plotted on a logarithmic scale (cf. Figure 1). As the graph illustrates, although The Theogony is not identical to the Homeric works, it is closer to them than it is to Apollonius's text.

${ }^{6}$ As briefly noted in our introduction, the definition of a "formula" remains controversial. Based on our data and for strictly practical reasons, we therefore limited the term "formula" to topolexes that occurred more than once in the same rhythmic position in the hexameter. This was also the sense in which we used the term "formulaicity". 


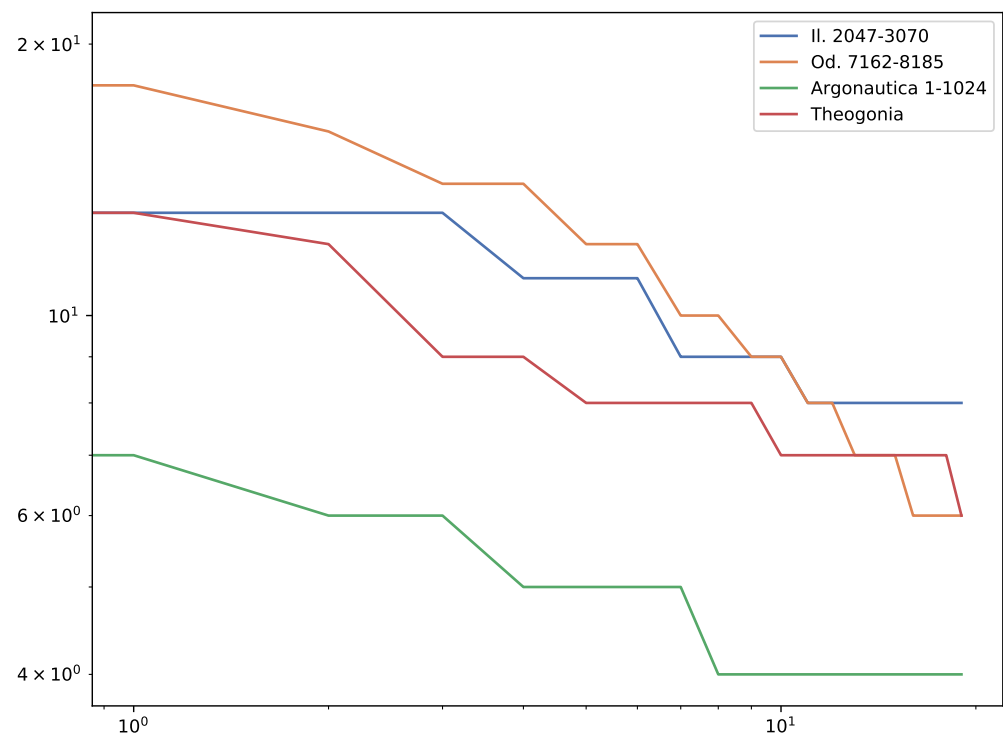

Figure 5: The 20 most common topolexes and their recurrence (content words only) plotted on a logarithmic scale

Figure 6 is analogous to the violin plot model in Figure 6 with the addition of The Theogony. Based on even this small sample, we may conclude that Hesiod demonstrates the same behavior regarding topolexes as Homer. This behavior is also characteristic of the formulaic style of poetry.

The formulaicity ratios for this corpus are as follows:

- The Iliad, 2047-3070: 1.30

- The Odyssey, 7162-8185: 1.32

- The Argonautica, 1-1024: 1.15

- The Theogony: 1.32

\section{A Comparative Stylometric Experiment}

One popular indicator in contemporary stylometry is the relative frequency of the most frequent words (MFW) (see Plecháč et al. 2018, including its bibliography). This indicator is obtained as follows: we count the number of times a given word occurs in a text and then divide this figure by the total word count. Once these values are obtained, we can choose a given number of most frequently used words. Based on these MFW, we can then perform a multivariate analysis.

To calculate the stylometric proximity between texts or sets of texts, the "distances" are measured between them. Just as we measure the distance between two points on a Cartesian plane, we calculate the "distance" between 


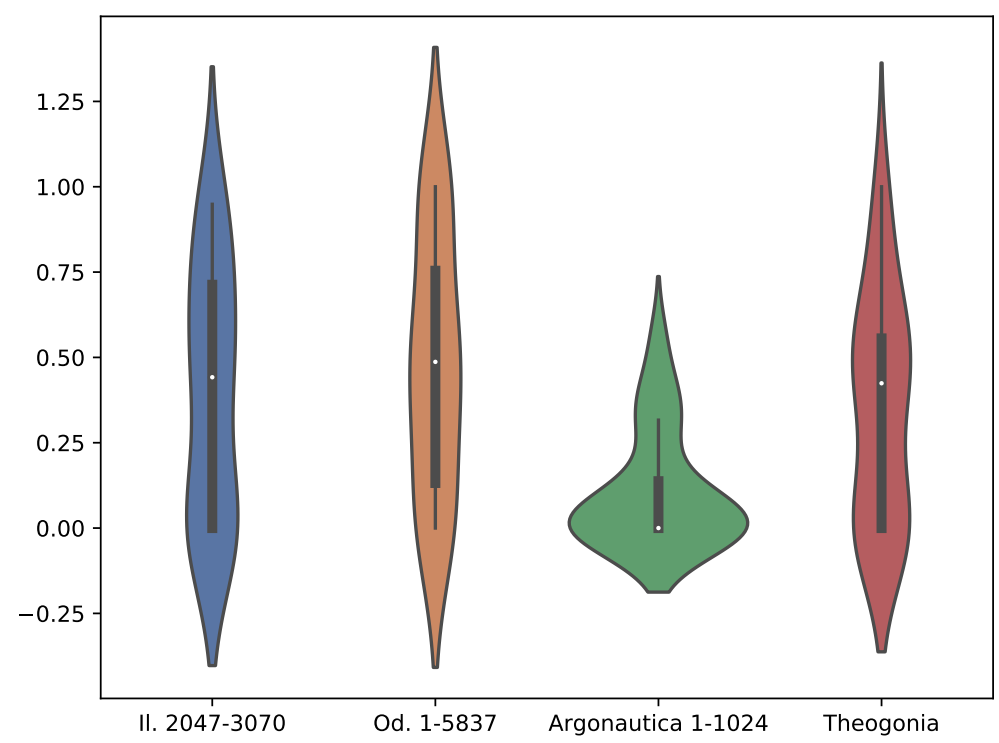

Figure 6: Total number of topolexes of each frequency (content words, from 1 to 50); normalized data

two texts (or sets of texts) based on the relative frequency of their most frequent words. Each text (or set of texts) is, thus, represented by a point in a multidimensional space where each coordinate is the value of the corresponding relative frequency, and the number of dimensions is the total number of most frequent words chosen for analysis. The distances thus obtained are then subjected to hierarchical clustering, and the outcome is often visualized as a tree diagram.

Generally speaking, the tree diagram that results from this cluster analysis is a graph with the following format: its $y$-axis shows the distances between the two texts while its $x$-axis shows the blocks established from the binary nodes based on those distances.

To assess the stylometric potential of topolexes, we compared the results of applying the clustering method to 1) the traditional indicator of MFW relative frequency and 2) the relative frequency of topolexes. Since we sought only to compare these two methods and were not interested in comparing the works with each other, we created a corpus consisting of Homer's The Iliad and Apollonius Rhodius' The Argonautica. We then ran the following test:

1. First of all, we divided The Iliad and The Argonautica into blocks of 750 lines each (this yielded slightly more than 5000 words per block, which is believed to be the minimum word count needed for this type of analysis to be efficient). We then calculated the distances between the texts and produced two tree diagrams: the first was based on the top 50 MFW while the second represented the 50 most common topolexes. 
As can be seen in Figures 7 and 8, when applied to blocks of this length, both indicators yielded reliable results. The blocks from The Iliad and The Argonautica are, thus, respectively grouped together and form two separate clusters.

2. We repeated the experiment with blocks containing 350 lines each. As Figures 9 and 10 show, ${ }^{7}$ both stylometric indicators again yielded good results.

3. We also achieved reasonably good results for both stylometric indicators when using smaller blocks of 100 lines each. To make this work, however, we had to extend the ranges to the 350 most common words and the 900 most common topolexes, as illustrated in Figures 11 and 12 (see footnote 7).

4. Finally, when using blocks smaller than 50 lines, we found that no matter how much we extended the frequency ranges (and even when we went as high as the 10,000 most common words/topolexes), we failed to obtain satisfactory results for either the MFW or the topolexis indicator (the best results can be seen in Figures 13 and 14; see footnote 7).

Our initial hypothesis was that topolexes might be a better stylometric indicator for verse texts. The results above did not, however, confirm our thesis: while topolexes allow us to correctly cluster fragments by author, they do not outperform the MFW in this respect.

\section{Conclusion}

We investigated the behavior of topolexes in a corpus of texts which included Homer's The Iliad and The Odyssey and Apollonius Rhodius' The Argonautica.

Our findings showed that Apollonius' text has a higher number of unique topolexes while Homer's works contain more high-frequency topolexes. The "formulaicity ratio", i.e. the ratio of the number of different topolexes in a text to its total topolexis count, is higher for Homer than it is for Apollonius. Our indicator, thus, accurately reflected the greater formulaicity of Homer's texts.

Our analysis of Hesiod's The Theogony by the same method demonstrated its similarity to Homer's poems in terms of topolexis behavior.

Finally, we ran a test to compare the performances of the topolexis and the MFW as stylometric indicators for determining authorship. We found that while topolexes enable the correct clustering of fragments by author, they do not outperform the MFW in this regard.

We have limited the current article to the presentation of the main quantitative results of our study. However a qualitative analysis of issues such as poetic syntax, style, and topolexis distribution by line has yet to be conducted.

\footnotetext{
7 Tree diagrams corresponding to Figures 9 to 14 can be found at: https://cutt.ly/ohzJfjY. That site also includes all of the texts scanned and tokenized by topolexis (in CSV format) as well as tables with full topolexis lists for each text sorted by frequency.
} 


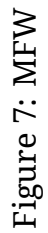


As a next step for future research, we envisage a study of typical topolexis sequences within the hemistich and the line as well as the application of our method to other verse forms. In the meantime, we hope that we have added another useful instrument to the toolkit for stylometric analysis.

\section{Acknowledgments}

This paper is part of a research project based at Lomonosov Moscow State University and supported by Russian Science Foundation Grant № 19-78-10132. We thank Mikhail Oslon for his help with preparing the English version of this paper.

\section{References}

Akimova, Marina Vyacheslavovna (2012). “Osip Maksimovich Brik. Ritm i sintaksis (Materialy k izucheniyu stixotvornoj rechi). Vstupitel'naya zametka, podgotovka teksta i primechaniya M. V. Akimovoj”. In: Slavyanskij stix, vol. 9. Moskva: Rukopisnye pamyatniki Drevnej Rusi, pp. 501-550. URL: http: //ruformalism.feb-web.ru/docusr/Brik-Akimova.pdf.

Akimova, Marina Vyacheslavovna (2015). "Tradicii izucheniya russkogo stixotvornogo sintaksisa: O. M. Brik i M. L. Gasparov”. In: Antropologiya kul'tury, vol. 5. Ed. by Marina Vyacheslavovna Akimova and Dmitrij Vadimovich Val' kov. Moskva: Novoe izdatel'stvo, pp. 351-356. uRL: https://www.academia. edu/15279097/.

Akimova, Marina Vyacheslavovna (2017a). "Citata ili klishe v poèticheskom tekste: popytka razgranicheniya”. In: M. L. Gasparovu-stixovedu: In memoriam. Ed. by Marina Vyacheslavovna Akimova and Marina Grigor' evna Tarlinskaya. Moskva: Yazyki slavyanskoj kul'tury, pp. 221-254. URL: https: //www.academia.edu/34475225/.

Akimova, Marina Vyacheslavovna (2017b). "Tradicii izucheniya russkogo stixotvornogo sintaksisa: B. I. Yarxo i M. L. Gasparov”. In: Trudy Instituta russkogo yazyka im. V.V. Vinogradova 14, pp. 89-112. URL: http://ruslang.ru/ doc/trudy/vol14/05-Akimova.pdf.

Belousova, Anastasia and Juan Sebastián Páramo Rueda (2019). "Macroanalysis of the strophic syntax and the history of the italian ottava rima". In: Quantitative Approaches to Versification. Ed. by Petr Plecháč, Barry Scherr, Tatyana Skulacheva, Helena Bermúdez-Sabel, and Robert Kolár. Prague: The Institute of Czech Literature of the Czech Academy of Sciences, pp. 23-30. URL: http://versologie.cz/conference2019/proceedings/belousova-paramorueda.pdf.

Brik, Osip Maksimovich (2012). "Ritm i sintaksis (Materialy k izucheniyu stixotvornoj rechi). Vstupitel'naya zametka, podgotovka teksta i primechaniya M. V. Akimovoj”. In: Slavyanskij stix, vol. 9. Moskva: Rukopisnye pamyatniki Drevnej Rusi, pp. 501-550. URL: http://ruformalism.feb-web.ru/docusr/BrikAkimova.pdf. 
Foley, John Miles (1985). Oral-Formulaic Theory and Research: An Introduction and Annotated Bibliography. New York: Garland Publishing, Inc.

Gasparov, Mixail Leonovich (1986). "Ritmiko-sintaksicheskaya formul'nost' v russkom 4-stopnom yambe”. In: Problemy strukturnoj lingvistiki. 1983. Moskva: Nauka, pp. 181-199.

Kruglova, Anastasia, Olga Smirnova, and Tatyana Skulacheva (2019). "Syntax and pauses in a verse line: Statistical analysis”. In: Quantitative Approaches to Versification. Ed. by Petr Plecháč, Barry Scherr, Tatyana Skulacheva, Helena Bermúdez-Sabel, and Robert Kolár. Prague: The Institute of Czech Literature of the Czech Academy of Sciences, pp. 113-124. URL: http://versologie.cz/ conference2019/proceedings/kruglova-smirnova-skulacheva.pdf.

Lord, Albert (1960). The Singer of Tales. Cambridge, Mass.: Harvard University Press.

Mueller, Martin (2009). The Iliad. London: Bristol Classical Press.

Nagy, Gregory (1990). “Greek Mythology and Poetics". In: Ithaca: Cornell University Press. Chap. Formula and Meter: the Oral Poetics of Homer, pp. 18-35. URL: http://nrs.harvard.edu/urn-3:hul.ebook:CHS_Nagy.Greek_ Mythology_and_Poetics.1990.

Parry, Milman (1928). L'épithète traditionnelle dans Homère. Paris: Les Belles Lettres.

Parry, Milman (1971). The Making of Homeric Verse: The Collected Papers of Milman Parry. Oxford: Clarendon Press.

Plecháč, Petr, Klemens Bobenhausen, and Benjamin Hammerich (2018). "Versification and authorship attribution: A pilot study on Czech, German, Spanish, and English poetry”. In: Studia Metrica et Poetica 5.2, pp. 29-54. Dor: 10.12697/smp.2018.5.2.02.

Sklaviadis, Sophia and James K. Tauber (2019). "Homeric Formulas and Meter". In: Quantitative Approaches to Versification. Ed. by Petr Plecháč, Barry Scherr, Tatyana Skulacheva, Helena Bermúdez-Sabel, and Robert Kolár. Prague: The Institute of Czech Literature of the Czech Academy of Sciences, pp. 237-244. URL: https://versologie.cz/conference2019/proceedings/sklaviadis-tauber.pdf. Tarlinskaja, Marina (2015). “Ants Oras: Did He Know Russian "Formalists”? In: Studia Metrica et Poetica 2.2, pp. 10-24. DoI: 10.12697/smp.2015.2.2.02.

Tver' yanovich, Kseniya Yur' evna (2008). Poètika Benedikta Livshica: Sistema stixa. S.-Peterburg: SYMPOSIUM. URL: https://www.academia.edu/29763494/. Tverianovich, Kseniia (2019). "Rhythm and Syntax in Aleksandr Sumarokov's Odes”. In: Quantitative Approaches to Versification. Ed. by Petr Plecháč, Barry Scherr, Tatyana Skulacheva, Helena Bermúdez-Sabel, and Robert Kolár. Prague: The Institute of Czech Literature of the Czech Academy of Sciences, pp. 255-262. URL: http://versologie.cz/conference2019/proceedings/ tverianovich.pdf. 